\title{
A Study on Service Failure That Influence Repurchase Intention in Online Retailing: A Study among Online Shoppers in Klang Valley
}

\author{
Tan Chee How ${ }^{1}$, Ho Khang $\mathrm{Yi}^{1}$, and Salini Devi Rajendran ${ }^{1 *}$ \\ ${ }^{1}$ Faculty of Business and Information Science, UCSI University, Jalan Menara Gading, 56000 Cheras, Kuala Lumpur, Malaysia.
}

\begin{abstract}
Online retailing sector is a huge potential market with boundless prospect, so now, reducing service failures and increasing customers' repurchase intention has become the first mission for every online retailer in order to increase their competitive advantages and market shares and to become the industry leader. The goals of this study is to identify the types of service failures that the online shoppers experiencing and which service failure is most critical toward repurchase intention of online shoppers. SPSS statistics analysis method has been used to analyze the data collected from the respondents. According to the result, it confirms that there are five types of service failures have significant relationship to the repurchase intention of online shippers. This study may likely to be a reference for related online retailer to examine their operation performance and customer loyalty in order to provide better services and boost up business in online retailing industry.
\end{abstract}

\section{INTRODUCTION}

With the increasing of the usage of internet among the world and the advancement of internet technology, online shopping has become a big trend of purchasing form for now and future. The rise of smartphone probably is a main factor or booster to the growth of ecommerce [1]. Nowadays, online retail sector become a highly competitive business environment. Due to the barrier to entry the market is very low, there are almost ten thousands of small online retail firm been establish every year [2], so to become a profitable and surviving in this market is very difficult.

Even though now more and more people are willing to get involve in online purchasing, but by comparing to offline purchase in term of amounts, online purchasing is still a small portion of it. This is due to that there are some concerns and negative feeling about online shopping for many consumers. According to a survey by E-Commerce-Milo, "lack of trust" is the main reason for why most of the people don't shop online [3]. The factors of "lack of trust" most probably are come from bad experiences or negative word-of-mouth about service failure of online shopping. Moreover, unlike offline purchase, online shoppers can't physically see or touch the actual product and they can't get the product immediately after payment, so these may be the main obstacles of building trust between firms and customers.
Furthermore, according to a research done by Nielson, over half of Malaysian's online shoppers (52\%) are still careful about giving credit card information when doing online payment due to the credit card frauds [4]. These kinds of security fears are one of the major factors why Malaysian consumers are more likely to purchase instore rather than do the financial transaction via online. Service failures also frequently occur because of incorrect suppliers selected to provide the materials or products that are sold.

Online retail sector is a huge potential market with boundless prospect. However, Malaysia's online retail sector is stuck in this situation due to the reasons mention above. The key to break through this stagnation situation are to eliminate the concern and worried of Malaysia's online shoppers, create an online shopping system that can make customer feel safe and satisfy with all of the services been delivered. So, now, every online retailer is actively seeking the way to increase their service quality and customers' repurchase intention in order to increase their competitive advantages and market shares and to become the industry leader. Therefore, this study investigate the types of services failure that online shoppers are experiencing and the most influence services failure toward repurchase intention of online shoppers in Klang Valley.

*Corresponding author's e-mail: salinidevi@ucsiuniversity.edu.my 


\section{METHODOLOGY}

In this study, quantitative research method will be conducted to examine the relationship between the dependent variable and independent variables. The quantitative research deals with the statistical analysis and numerical data to provide quantitative information which used to determine the variables and relationship between the service failure and the problems occur in the online shopping. Besides, the descriptive research is chosen to provide the description of the participants, which will participate in the survey, and help to determine the hypothesis.

\subsection{Data Collection Method}

Data Collection method is used to collect and prepare data to test the hypothesis in the further study. Quantitative data collection methods rely on random sampling and structured data collection instruments that fit diverse experiences into predetermined response categories. In this research, both primary data and secondary data will be used.

In this study, the questionnaire, which is one of the methods in survey, will be chosen to primary data collection. The questionnaire is a method that makes use of the checklist and rating scales that help to simplify and quantify people's behaviors and attitudes. The method enables to reach large sample from the population can be contacted at relatively low cost.

In this study, secondary data usually collected form the external sources such as journals, books, magazines, newspaper, libraries or from the internet are used to conduct the knowledge of the problems occur in online retailing and how they lead to service failures.

\subsection{Sampling Design}

\subsubsection{Target Population}

The target population in this study is focus on the online consumers who are around the Klang Valley. Besides, the respondents should be the online shoppers that have experienced service failures that occur in the online shopping before.

\subsubsection{Sampling Location}

The sampling location will focus at Klang Valley [5]. Therefore, the questionnaires will only be distributed to online consumers in Klang Valley.

\subsubsection{Sampling Size}

It is estimated to conduct the surveys among 150 respondents. The respondents should have experiences of service failures occur in the online shopping and they need to use the experiences and knowledge to answer the questionnaires in order to have accurate data.

\subsubsection{Sampling Technique}

The sampling technique is divided into two categories which are probability and non-probability. In this study, the non-probability sampling method is chosen to determine the sample. It is because the randomization in choosing sample is impossible since the population as almost limitless.

Convenience sampling is a sampling method where the subject was chosen due to their convenient accessibility and proximity. The advantages of convenience sampling are that it is considered easiest, cheapest and least time consuming. Convenience sampling is chosen in this study because the population cannot be defined and it can help the researchers to target respondents easily.

\subsection{Variable Measurement}

The dependent variable in this study is service failure in online retailing and the independent variables are delivery problem, website design problem, security problem, product quality problem and customer service problem.

Closed-ended questions are giving multiple choice answer to the respondents that require the respondents to pick the answer taking into account the given various decision answer. This questionnaire is categorized into 3 sections, which are Section A (Socio- Demographic Profile), Section B (Consumer's Online Shopping Practice) and Section $\mathrm{C}$ (Factors Influence Service Failure).

In section A, details information of respondent's social demographic will be collected, which include age group, race, education level, gender, occupation and monthly income level.

In section B will be asked for own opinion about consumer's online shopping practice which is the experience of service failure in online retailing. The respondents are requiring answer structured question such multiple-choice and scales.

Lastly, section C it will be asked for respondent's opinion about factors of service failure in online retailing in Malaysia. It includes questions that associated with measurement of independent variables which are delivery problem, website design problem, security problem, product quality problem and customer service problem.

\subsection{Pilot Testing}

Pilot test is small-scale of test that conducted by the researchers before the actual research is carried out [6]. It is used to validate a survey instrument. The pilot study was carried out to evaluate the factors of service failure in online retailing by employing a pre-test and post-test with a sample of target respondents $(n=30)$. The actual research is depending on pilot test in order to test the 
feasibility and suitability. Therefore, pilot test also known as feasibility test or suitability test.

\subsection{Data Analysis}

\subsubsection{Descriptive Analysis}

The subjects that are studied, missing values, maximum and minimum values of the variables and the relationship between the variables are tested in descriptive analysis [7]. Descriptive analysis includes summarizing and transforming data into an understandable and interpretable mode. The demographic data of respondents used descriptive analysis to describe the characteristics through frequency distribution, percentage, mean and standard deviation [7].

\subsubsection{Normality test}

Normality test is conducted in order to find out whether a sample or data fit the normal distribution or not. Normality test will also be used to test whether the data had been drawn from the normally distributed populations or not. So if the skewness and kurtosis values in the range of -1.96 to +1.96 during the normality test, the data will be considered as normal. However, if the skewness and kurtosis values are smaller than -1.96 or larger than +1.96 , the data will be considered as not normal $[6,8]$.

\subsubsection{Reliability test}

The aim of reliability test is to determine the consistency and stability with which the research measures the constructs [9, 12]. Reliability is a critical element of validity but it is not sufficient to measure validity. In another word, which means that a test can be reliable but not necessary valid, whereas a test cannot be valid yet unreliable [13]. Internal consistency test compares the same instrument to ensure the existing of correlation between the two instruments. Therefore, Cronbach's alpha reliability analysis method will be used to calculate the intensity and direction of the relationship between two variables [14]. The correlation coefficient value only ranged from 0 to 1 [15]. The higher the coefficient esteems the more solid the information estimation.

\subsubsection{Validity test}

Validity can be defined as the potential of research instrument that been used to measure the authentic value of an approach in the hypothesis [6]. This also can be understood as if there is no consistency in the conceptual and operational definition of the concept, the validity will be low.

Since this study is a quantitative research, validity in quantitative research will be discussed. Quantitative research is used to state the observed behavior by using numbers and mathematical operations [6]. Quantitative research is mainly focuses on the accurate measurement and hypothesis testing based on the sample that has been studied through statistics in the data analysis.

\subsubsection{Multiple Regression Analysis}

As indicated by Mark et.al [16], multiple regressions are measure of direct affiliation that examines a straight-line relationship. Standard coefficient (Beta) shows the relative significance of the independent variables [16]. The higher quality in Beta shows a higher effect of the indicator on the needy variable [16]. Multiple regression method was embraced on the grounds that there is stand out metric ward variable and seven metric independent variables. Likewise, it is suitable to utilize multiple regressions given all the independent variables can be measured by utilizing the same scale. The multiple regression equation as:
$\mathrm{Y}=\mathrm{a}+\mathrm{b} 1$ (Delivery Problem) $+\mathrm{b} 2$ (Website Design Problem) + b3(Security Problem) + b4(Product Quality Problem) + b5(Customer Service Problem)+ $\epsilon$
Where, $\quad \mathrm{Y}=$ Dependent Variable
$\mathrm{X}(\mathrm{s})=$ Independent Variable $(\mathrm{s})$
$\mathrm{a}, \mathrm{b}=$ Constants to be estimated $\epsilon=$ Error

\subsection{Hypothesis of the study}

H1: There is a significant relationship between delivery problem and repurchase intention in online retailing.

H2: $\quad$ There is a significant relationship between website design problem and repurchase intention in online retailing.

H3: There is a significant relationship between security problem and repurchase intention in online retailing.

H4: There is a significant relationship between product quality problem and repurchase intention in online retailing.

H5: There is a significant relationship between customer service problem and repurchase intention in online retailing.

\section{RESULT AND DISCUSSION}

There are total 150 sets of questionnaire were distributed to the online shoppers in Klang Valley. The data from questionnaire was analyzed by using SPSS version 22 .

\subsection{Normality Test}

Based on Table 1, all data are normally distributed due to that the skewness and kurtosis value of all data are inside the range of -1.96 to +1.96 . In order to let the data to be normally distributed, the skewness and kurtosis values should be in the range of -1.96 to +1.96 [6]. 
Table 1. Normality Test of Skewness and Kurtosis of Socio-Demographic Information

\begin{tabular}{ccc}
\hline Socio-Demographic & Skewness & Kurtosis \\
\hline Gender & 0.244 & -1.967 \\
Age & 0.890 & 0.142 \\
Ethnic Group & 0.047 & -0.774 \\
Religion & -0.073 & -1.105 \\
Marital Status & 0.847 & -1.300 \\
Highest Education Level & -1.092 & 0.364 \\
Employment Status & 0.524 & -1.566 \\
Income & 0.656 & 0.103 \\
Electronic Devices & 1.066 & -0.031 \\
\hline
\end{tabular}

Based on Figure 1, the histogram shows that the data is normally distributed due to that it displays a high distribution in the middle and a low distribution at both the left and right ends. The skewness(-0.753) and kurtosis(-0.019) values are inside the normal distribution range Based on Figure 2, the histogram shows that the data is normally distributed due to that it displays a high distribution in the middle and a low distribution at both the left and right ends. The skewness $(-0.860)$ and kurtosis $(0.153)$ values are inside the normal distribution range.

Based on Figure 3, the histogram shows that the data is normally distributed due to that it displays a high distribution in the middle and a low distribution at both the left and right ends. The skewness(-0.682) and kurtosis(-0.175) values are inside the normal distribution range. Based on Figure 4, the histogram shows that the data is normally distributed due to that it displays a high distribution in the middle and a low distribution at both the left and right ends. The skewness(-0.829) and kurtosis $(0.075)$ values are inside the normal distribution range.

Based on Figure 5, the histogram shows that the data is normally distributed due to that it displays a high distribution in the middle and a low distribution at both the left and right ends. The skewness $(-0.813)$ and kurtosis(-0.036) values are inside the normal distribution range. Based on Figure 6, the histogram shows that the data is normally distributed due to that it displays a high distribution in the middle and a low distribution at both the left and right ends. The skewness (0.531) and kurtosis $(-0.240)$ values are inside the normal distribution range.

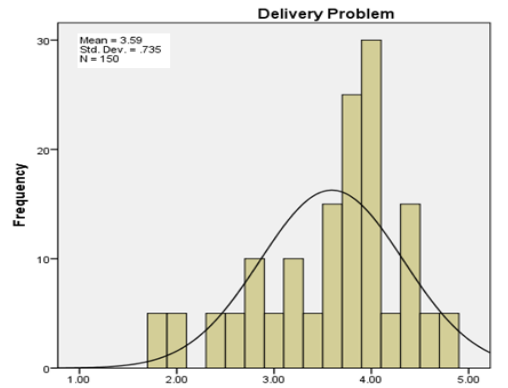

Figure 1. Normality Test of Delivery Problem

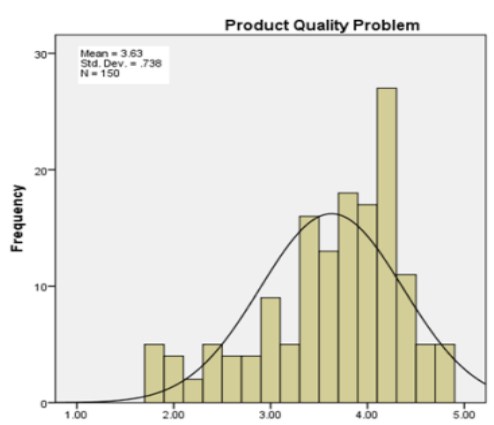

Figure 4. Normality Test of Product Quality Problem

\subsection{Reliability Test}

According to Table 2, it shows that the Cronbach's Alpha value is 0.972 after analyzed with testing of 26

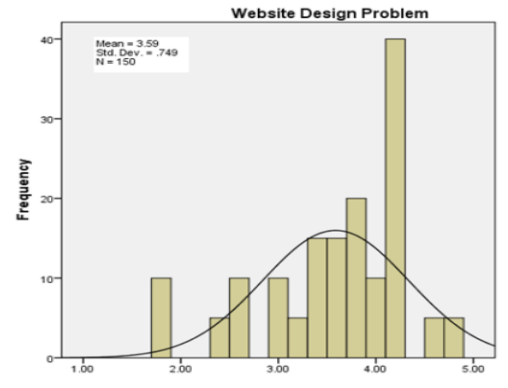

Figure 2. Normality Test of Website Design Problem

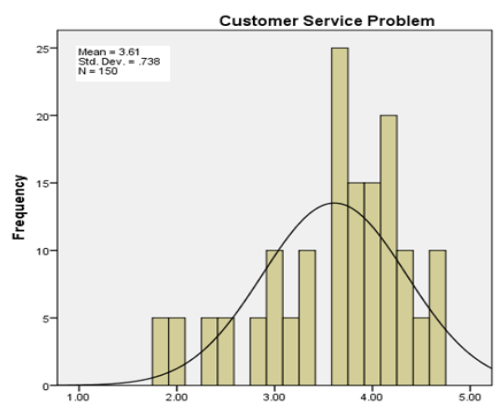

Figure 5. Normality Test of Customer Service Problem

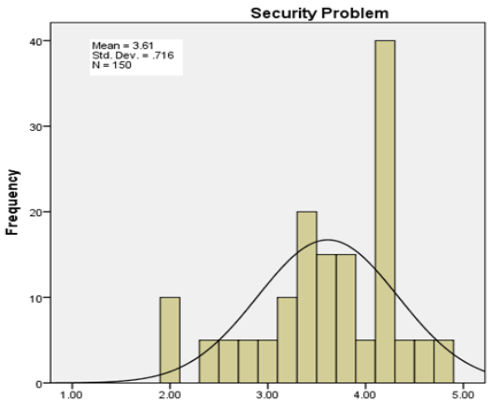

Figure 3. Normality Test of Security Problem

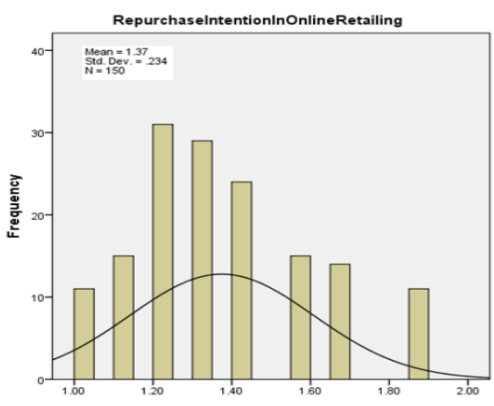

Figure 6. Normality Test of Repurchase Intention in Online retailing

items of the independent variables, which means that it is highly reliable due to the rules of Thumb of Cronbach's alpha coefficient size stated that value higher than 0.9 is excellent in terms of strength of associations [15]. 
Table 2. Reliability Test of Independent Variables

\begin{tabular}{lcc}
\hline Reliability Statistics & & \\
\hline Independent Variables & Cronbach's Alpha & No. of Items \\
\hline Reliability Test of Independent Variables & 0.953 & 26 \\
\hline
\end{tabular}

Table 3 shows that the reliability of dependent variable and its Cronbach's alpha value is 0.659 , which means that the dependent variables (repurchase intention

Table 3. Reliability Test of Dependent Variables in online retailing) is reliable according to the rules of Thumb of Cronbach's alpha coefficient size [15].

Reliability Statistics
Independent Variables
Repurchase Intention in Online Retailing
Table 4 shows the result of reliability test on five of
dependent variables. It shows that the Cronbach's
lpha values of all the independent variables are
easureen range of 0.723 to 0.791 , which means the
eavery problem has lowest Cronbach's alpha values of
723 , followed by website design problem with the

Cronbach's Alpha

0.659

Cronbach's alpha values of 0.741 , security problem has alpha coefficient of 0.743 and product quality problem has alpha coefficient of 0.745 . The independent variables of customer service problem have the highest alpha coefficient of 0.791 which means that it has the highest reliability among all the variables.

\begin{tabular}{cccc}
\multicolumn{5}{c}{ Table 4. Reliability Statistics (Independent Variable) } \\
\hline Reliability Statistics & & & \\
\hline No & Independent Variables & Cronbach's Alpha & No. of Items \\
\hline 1 & Delivery Problem & 0.723 & 5 \\
2 & Website Design Problem & 0.741 & 5 \\
3 & Security Problem & 0.743 & 5 \\
4 & Product Quality Problem & 0.775 & 5 \\
5 & Customer Service Problem & 0.791 & 6 \\
\hline
\end{tabular}

\subsection{Descriptive Analysis}

Table 5 tabulates the social demographic profile, about $56 \%$ of the respondents are male and the remaining is female. Majority of the respondents are age between 19 and 25 , about $46 \%$ of the respondents. The ethnic groups consist of Malay, Chinese and Indian contributes by $24.7 \%, 54.7 \%$ and $20.7 \%$ respectively. Regarding the religion, $24.7 \%$ is Islam, $42.6 \%$ is Buddhism, $32.7 \%$ is
Christians, and there is 1 respondent belong to other religion majority of the respondents are single about $69.3 \%$ and the rest are married. For highest education level, majority of the respondents are Bachelor degree about $66 \%$, follows by Diploma about $21.3 \%$, Secondary school about $10.7 \%$ and Master degree about $2 \%$. Besides that, majority of the respondents are employed for wages which is $56 \%$ and then highest percentage of the income group is between RM1001 - RM 2500 about $48 \%$.

Table 5. Social Demographic Profile

\begin{tabular}{lccc}
\hline Items & Category & Frequency (n) & Percentage (\%) \\
\hline Gender & Male & 84 & 56.0 \\
& Female & 66 & 44.0 \\
\hline Age & 19 to 25 & 69 & 46.0 \\
& 26 to 35 & 56 & 37.3 \\
& 36 to 45 & 20 & 13.3 \\
& 46 and above & 5 & 3.3 \\
\hline Ethnic Group & Malay & 37 & 24.7 \\
& Chinese & 82 & 54.7 \\
& Indian & 31 & 20.7 \\
\hline Religion & Islam & 37 & 24.7 \\
& Buddhism & 63 & 42.0 \\
& Christians & 49 & 32.7 \\
& Other & 1 & 0.7 \\
\hline Marital Status & Single & 104 & 69.3 \\
& Married & 46 & 30.7 \\
\hline Highest Education Level & Secondary School & 16 & 10.7 \\
& Diploma & 32 & 21.3 \\
& Bachelor Degree & 99 & 66.0 \\
& Master & 3 & 2.0 \\
\hline Employment Status & Employed for Wages & 84 & 56.0
\end{tabular}




\begin{tabular}{lccc} 
& Self-employed & 20 & 13.3 \\
& A Student & 46 & 30.7 \\
\hline Income Level & Less than 1000 & 51 & 34.0 \\
$(\mathrm{RM})$ & 1001 to 2500 & 72 & 48.0 \\
& 2501 to 3500 & 22 & 14.7 \\
\hline
\end{tabular}

Figure 7 shows the majority of the respondents are using desktop computer for online shopping, there are 84 respondents and take $56 \%$ of total respondents. Besides, there are 34 respondents who are using their smartphone for online shopping which take $22.7 \%$ of total respondents. Moreover, there are 22 respondents who are using their tablet for online shopping which take $14.7 \%$ of total respondents. Lastly, there are 10 respondents who are using Smart TV (shopping channel) for online shopping which take $6.7 \%$ of total respondents.
Figure 8 shows there are 52 respondents shop online once a month which accounted $34.7 \%$ of the total respondents. Besides, there are 35 respondents shop every week which also represent $23.3 \%$ of respondents. Moreover, there are 29 respondents shop online twice a month. Meanwhile, there are 20 respondents who shop online once in six months and 11 respondents shop online once in a year. There are only 3 respondents who shop online every day which also accounted only $2 \%$ of total respondents.

\subsubsection{Online Shopping Behavior of Respondents}

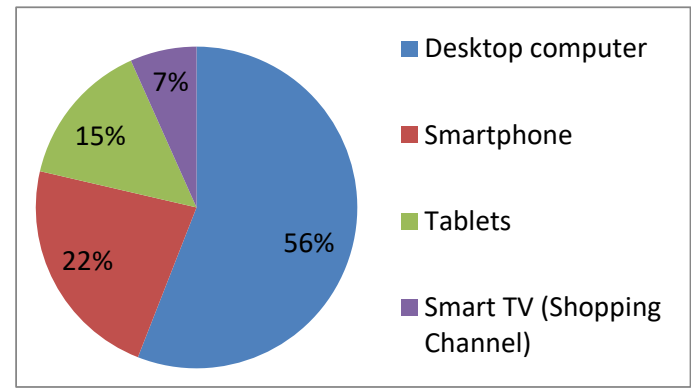

Figure 7. Type of Device been use for online shopping

Figure 9 shows the type of products that respondents usually purchase at online retailing websites, fashion and accessories is the type of product that respondents purchase most at the online retailing websites. It followed by the consumer electronics and health and beauty products with almost $52 \%$. Besides, mobiles and tablets is the type of products that respondents purchased least apart from the other type of products that are not in the questionnaire.

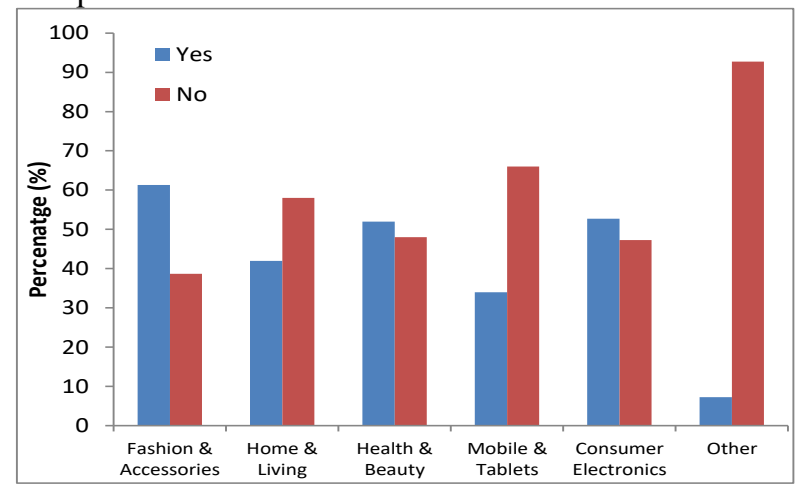

Figure 9. Online shopping behavior of respondents (Type of products respondents usually purchase)

All of the respondents have met service failures from online shopping before. Figure 11 shows 46 out of 150 respondents met service failures once in five purchases from online retailing websites. Besides, $23.3 \%$ of the

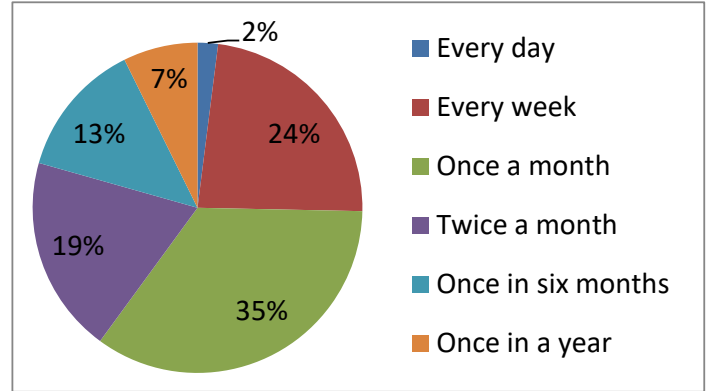

Figure 8. Online shopping behavior of respondents (How frequent respondents shop online)

Figure 10 shows there are 102 out of 150 respondents feel convenient to shop online, it is the reason that most driven respondents to shop from the online shopper. Besides, 88 respondents think that time saving is the reason that they shop online which is the second highest of all the reason. Meanwhile, it followed by diversity of choices, lower price and price comparison with $48.7 \%$, $45.3 \%$ and $40.7 \%$ respectively.

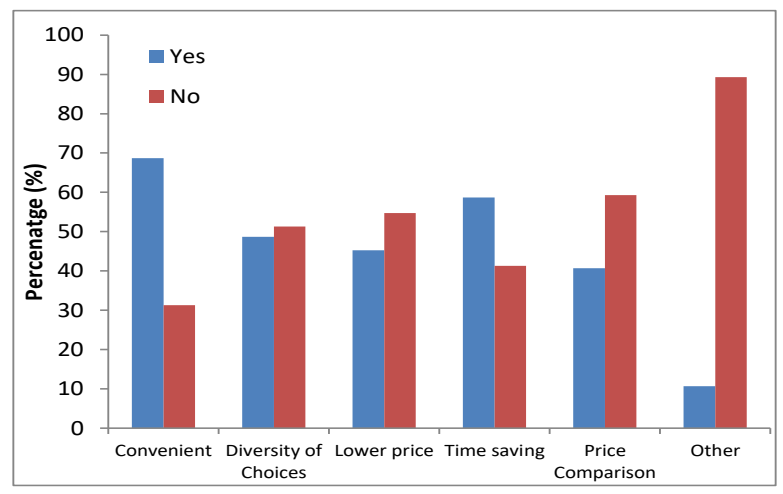

Figure 10. Online shopping behavior of respondents (Reason to shop online)

respondents which is 35 respondents met service failures once in four purchases. It followed by that the respondents met service failures once in three purchases and once in ten purchases which represent $13.3 \%$ and 
$12.7 \%$ respectively. There are only 7 respondents who met service failures in every of their purchase online.

Figure 12 shows 104 respondents with $69.3 \%$ have met delivery problem from online shopping before which is the highest among all type of service failures. Besides, 84 out of 150 respondents have met product quality problem before. Moreover, $51.3 \%$ of the respondents which are 77 respondents have met security problem before. Lastly, there are 69 respondents with $46 \%$ have met customer services problem while 56 respondents with $37.3 \%$ have met the website design problem which also the lowest type of service failure that respondents have met.

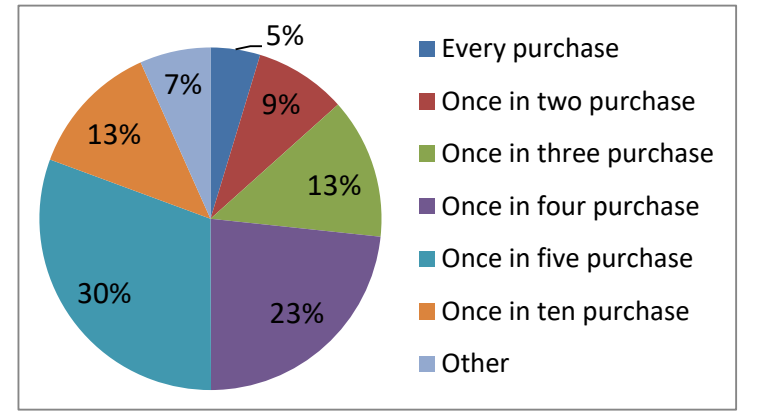

Figure 11. Frequency of Service failures that respondents met

Figure 13 shows the most common service failures from online shopping those respondents met before, the delivery problem is the most common service failure that respondents met on the online shopping, and there are 78 respondents with $52 \%$ that met delivery problem before.

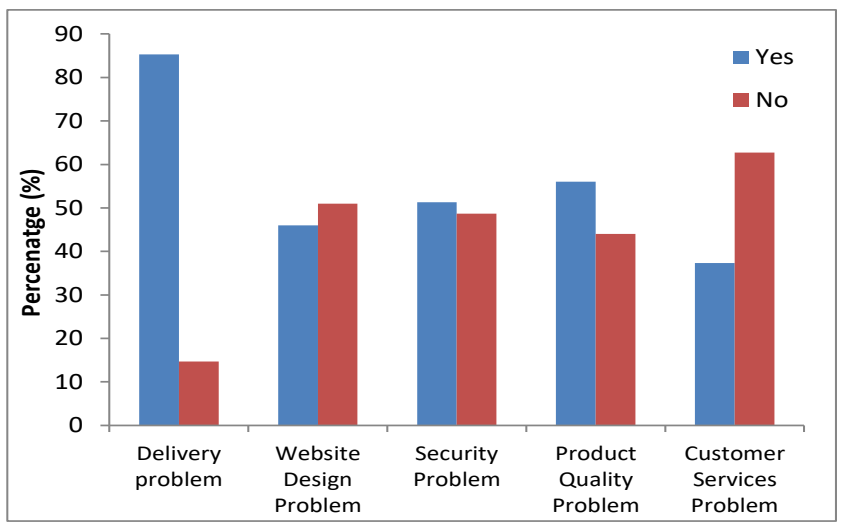

Figure 12. Types of service failures that respondents met before

It followed by the product quality problem, security problem, website design problem and customer services problem which represent $17.3 \%, 14.7 \%, 10.7 \%$ and $5.3 \%$ respectively.

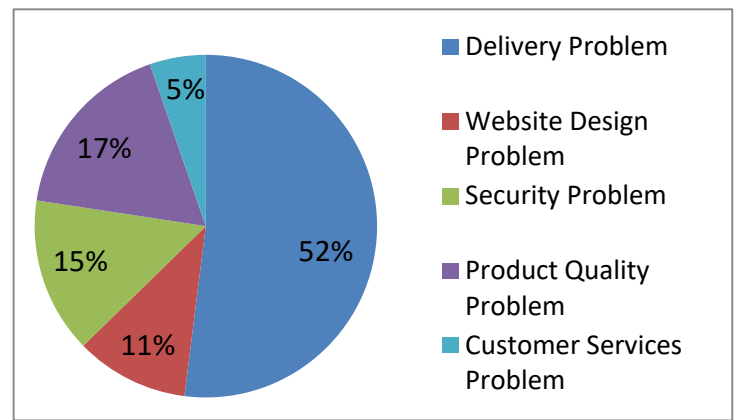

Figure 13. Service failures (Most common service failures respondents met before)

\subsection{Multiple Regression Analysis}

Table 6 shows the result of multiple regression tests which can use for test of significant purpose. Table 6 shows that the significant value of delivery problem is 0.000 . This value is less than 0.05 , thus, H1 is accepted, which also means delivery problem has significant relationship to repurchase intention in online retailing. This finding is similar to Ying-Feng Kuo (2009), which also indicated that delivery problem negatively influences repurchase intention in online retailing by studying purchasing behavior in online retailing [17].

The significant value of website design problem is 0.022 . Since the value is less than 0.05 , thus, $\mathrm{H} 2$ is accepted, which also means delivery problem has significant relationship to repurchase intention in online retailing. This finding is similar to finding of Kuster Ines (2011), which state that website with design problem is a big failure for the online retailer, because it would greatly impact on online consumer's repurchase intention, perception and behavior to the e-retailer's website and company's image [18].

The significant value of security problem is 0.022 . Since the value is less than 0.05 , thus, H3 is accepted, which also means security problem has significant relationship to repurchase intention in online retailing. This finding is similar to Prasad [19], identify that security risk has given negative impact on shopper's repurchase intention in online shopping. Besides, this finding is also supported by Bo Dai et al. [20] and Janda [21].

The significant value of product quality problem is 0.004 . Since the value is less than 0.05 , thus, $\mathrm{H} 4$ is accepted, which also means product quality problem has significant relationship to repurchase intention in online retailing. This finding is similar to Ko [22], which indicates that product quality problem will cause the dissatisfaction of the buyers and it will influence the repurchase intention of the buyers. 
The significant value of customer service problem is 0.026. Since the value is less than 0.05 , thus, H5 is accepted, which also means customer service problem has significant relationship to repurchase intention in online retailing. This finding also similar to Betsy
Holloway [23], which stated that customer service problems will affect the online shoppers' satisfaction or trustworthy to the online retailers thus will influence the repurchase intention of them.

\begin{tabular}{|c|c|c|c|c|c|}
\hline \multicolumn{6}{|l|}{ Coefficients $^{\mathrm{a}}$} \\
\hline Model & $\begin{array}{r}\mathrm{Un} \\
\mathrm{C}\end{array}$ & $\begin{array}{l}\text { ardized } \\
\text { cients }\end{array}$ & $\begin{array}{l}\text { Standardized } \\
\text { Coefficients }\end{array}$ & & \\
\hline 1 & $\mathrm{~B}$ & Std. Error & Beta & $\mathrm{t}$ & Sig. \\
\hline (Constant) & 2.530 & .062 & & 40.492 & .000 \\
\hline Delivery Problem & -.112 & .026 & -.342 & -4.234 & .000 \\
\hline Website Design Problem & -.048 & .021 & -.151 & -2.311 & .022 \\
\hline Security Problem & -.053 & .023 & -.161 & -2.322 & .022 \\
\hline Product Quality Problem & -.070 & .024 & -.203 & -2.935 & .004 \\
\hline Customer Service Problem & -.045 & .020 & -.138 & -2.242 & .026 \\
\hline
\end{tabular}

a. Dependent Variable: Repurchase Intention

Table 7 shows the $\mathrm{R}$ value is 0.850 , $\mathrm{R}$ Square value is 0.723 and moreover adjusted $\mathrm{R}$ Square is 0.713 , which means that there are totally $72.3 \%$ of the variation repurchase intention in online retailing can be explained from the five independent variables. ANOVA table in Table 8 shows that the overall model is significant with $\mathrm{F}$ ration $=75.057$ and $\mathrm{P}=0.000$

Table 7. Model Summary

\begin{tabular}{ccccc}
\hline Model & $\mathrm{R}$ & $\mathrm{R}$ Square & Adjusted R Square & Std. Error of the Estimate \\
\hline 1 & $.850 \mathrm{a}$ & .723 & .713 & .12531 \\
\hline
\end{tabular}

a. Predictors: (Constant), Delivery Problem, Website Design Problem, Security Problem, Product Quality Problem, Customer Service Problem

Table 8. ANOVA of Delivery Problem, Security Problem, Website Design Problem, Product Quality Problem, Customer Service Problem

\begin{tabular}{llccccc}
\hline ANOVA $^{\mathbf{a}}$ & & & & & \\
\hline Model & & Sum of Squares & $\mathrm{df}$ & Mean Square & $\mathrm{F}$ & Sig. \\
\hline 1 & Regression & 5.893 & 5 & 1.179 & 75.057 & $.000^{\mathrm{b}}$ \\
& Residual & 2.261 & 144 & .016 & & \\
& Total & 8.154 & 149 & & & \\
\hline
\end{tabular}
a. Dependent Variable: Repurchase Intention
b. Predictors: (Constant), Delivery Problem, Website Design Problem, Security Problem, Product Quality Problem, Customer Service Problem

Meanwhile, the following equation is created. $\mathrm{Y}=\mathrm{a}+$ b1 (Delivery Problem) + b2(Website Design Problem) + b3(Security Problem) + b4(Product Quality Problem) + b5(Customer Service Problem) $+\epsilon$. Repurchase Intention in Online Retailing $=2.530-0.112$ delivery problem 0.048 website design problem - 0.053 security problem 0.070 product quality problem -0.045 customer service problem. Thus, there is a negative relationship between delivery problem, website design problem, security problem, product quality problem and customer service problem.

Moreover, the standardized coefficient (beta value) shows that which independent variables are the most and least influence toward repurchase intention in online retailing. According to Table 6 shows that the independent variables that influence most to the repurchase intention is delivery problem due to it has highest beta value between all independent variables, which is -0.112 . It means that one unit increase in delivery problem will also decrease repurchase intention in online retailing by 0.112 units.

Besides, it followed by product quality problem (- 0.070), security problem (- 0.053), website design problem (0.048 ) and customer service problem has the lowest beta value (- 0.045) among others independent variables, which means that it has the least influential effect toward repurchase intention in online retailing.

\section{CONCLUSION}

The five independent variables or services failures been identified that will affect repurchase intention in online retailing among online shoppers in Klang Valley, which are delivery problem, website design problem, security problem, product quality problem and customer services problem. According to the results, all five hypotheses are supported by significant level less than 0.05 , which means that all five of the hypotheses $(\mathrm{H} 1, \mathrm{H} 2, \mathrm{H} 3, \mathrm{H} 4$ \& H5) in this research has been accepted. 


\section{References}

1. Wahab, S.N., Rajendran, S.D., Yeah N.K., \& Deng Y. (2017). Antecedents Influencing E-Service Quality towards Customer Loyalty among Malaysian Online Shoppers. 3rd International Conference on Advanced Research in Business and Social Sciences, 29-30 March, 337-346, Langkawi Malaysia

2. Laudon, K. a. (2009). E-Commerce Business. Technology. Society, 5th edition, Prentice Hall, New Jersey.

3. WONG, C. (2016). 8 facts on mobile commerce growth in Malaysia. Retrieved from eCommerceMILO: http://www.ecommercemilo.com/2016/04/8facts-on-mobile-commerce-growth-malaysia.html

4. Nielsen. (2014). Malaysians Rank among the World's Most Avid Online Shoppers.

5. Wahab, S.N., \& Khong W.L. (2018). Multiple Linear Regression Modelling of Parcels' Distribution Design Factors and online Shopping Customer Satisfaction. International Journal of Modelling in Operations Management, 7(2), 95-110.

6. Chua, Y. (2012). Mastering Research Methods. Malaysia: McGraw-Hill.

7. Baker, T. (1994). Doing Social Research (2nd Edn.). New York.

8. Wahab, S.N., Bahar, N. \& Mat Radzi, N.A. (2019). An Inquiry on Knowledge Management in Thirdparty Logistics Companies. International Journal of Business Innovation and Research, DOI: 10.1504/IJBIR.2020.10024101.

9. Teo, A.C., Tan, G.W.H., Cheah, C.M., Ooi, K.B \& Yew, K.T. (2012). Can the Demographic and Subjective Norms Influence the Adoption of Mobile Banking?', International Journal of Mobile Communications, Vol. 10 No. 6, 578-597.

10. Wong, C.H., Tan, G.W.H., Tan, B.I and Ooi, K.B. (2015). Mobile Advertising: The Changing Landscape of the Advertising Industry', Telematics and Informatics, Vol. 32 No.4, 720-734.

11. Wahab, S.N., Sayuti, N.M. \& Talib, M.S.A. (2018). Antecedents of Green Warehousing: A Theoretical Framework and Future Direction. International Journal of Supply Chain Management, 7(6), 382388.

12. Wahab, S.N., Lay, Y.F., Koay, W.L., \& Hussin, A.A.A, (2019). Usage of Pedestrian Bridge among the Urban Commuters in Kuala Lumpur. International Journal of Operational Research, DOI: 10.1504/IJOR.2021.10019276.

13. Malhotra, I. N. (2006). A decision-making approach. New Jersey: Prentice Hall.

14. Wahab, S.N, Olugu, E.U., Lee, W.C., \& Tan, S.Y. (2018). Big data analytics adoption in Malaysia warehousing industry. The 32nd International Business Information Management Association Conference, IBIMA 2018, 2349-2365, 15-16 November, Seville Spain.

15. Hair, J. F. Jr., Babin, B., Money, A. H., \& Samouel, P. (2003). Essentials of business research methods.
New Jersey: John Wiley \& Sons.

16. Mark, P. (2009). Research Methods for Business Students 5th Edition.

17. Ying-Feng Kuo, S.-T. Y.-H. (2009). Online auction service failures in Taiwan: Typologies and recovery strategies. Electronic Commerce Research and Applications, 183-193.

18. Kuster. (2011). Sucessful of SME through consumer focus groups. International journal of Quality and reliability, pg132-154.

19. Prasad, C. a. (2009). "Determinants of shopper behavior in e-tailing: An empirical analysis". Paradigm, 73-83.

20. Dai, B. Forsythe, S. \& Kwon, W-S. (2014). The Impact of Online Shopping Experience on Risk Perceptions and Online Purchase Intentions : Does Product Category Matter? Journal of Electronic Commerce Research, 15(1), 13-24.

21. Janda, S. \&. (2004). Exploring Consumer Concerns Related to the Internet. Journal of Internet Commerce, pg1-21.

22. Ko, H. J. (2004). Cross-Cultural Differences in Perceived Risk of Online Shopping. Journal of Interactive Advertising, 4(2), 20-29.

23. Holloway, B. B., \& Beatty, S. E. (2003). Service Failure in Online Retailing: A Recovery Opportunity. Journal of Service Research, 6(1), 92105. https://doi.org/10.1177/1094670503254288 